\title{
Az elektródasor visszatekeredésének kimutatása transzimpedanciamátrix (TIM)-vizsgálattal cochlearis implantátumban
}

\author{
Nagy Roland dr.* - Perényi Ádám dr.* - Dimák Balázs dr. \\ Csanády Miklós dr. - Kiss József Géza dr. - Rovó László dr. \\ Szegedi Tudományegyetem, Általános Orvostudományi Kar, \\ Fül-Orr-Gégészeti és Fej-Nyaksebészeti Klinika, Szeged
}

\begin{abstract}
Bevezetés: Az elmúlt években a cochlearis implantátum a súlyos halláskárosodás vagy a teljes siketség rutinszerú és hatékony kezelési eszközévé vált. Korunk egyik leggyakrabban használt és leghatékonyabb újitása a cochlearis implantációban a perimodiolaris vékony elektródasorok alkalmazása. A cochlea középtengelyét, a modiolust szorosan ölelő atraumatikus elektródasor igen meggyőző eredménnyel bizonyítja népszerúségét, mind az elektrofiziológiai mérések során, mind az akusztikus hallás megőrzése terén nyújtott teljesítményével. Ugyanakkor igen kevés publikáció írja le az elektródasor nem megfelelő helyzetének előfordulási gyakoriságát, pontosabban a visszatekeredését a csúcsi szakaszon

Célkitüzés: Tanulmányunk célja olyan szoftveres technika, a transzimpedancia-mátrix (TIM) beillesztése a rutin intraoperatív elektrofiziológiai mérési metodikák közé, amely képes objektív diagnosztikai lehetőséget biztosítani ahhoz, hogy korán felismerhessük a cochlearis implantátum elektródasorán keletkezett hurkot.

Módszer: Hároméves kisgyermek kétoldali cochlearis implantációját követően, posztoperatív röntgenfelvételen a bal oldalon az elektródasor megfelelő pozíciója figyelhető meg, míg a jobb oldalon az intracochlearis elektródasor végének visszatekeredése igazolódott. Képalkotó vizsgálatot követően elektrofiziológiai metódusként TIM-vizsgálatot végeztünk. Az eljárás során a méróeszköz a kijelölt stimuláló elektródákon $1 \mathrm{~V}$ nagyságrendű feszültséget közöl állandó áramerősség mellett a cochlea közel eső struktúrái felé. Mérőelektródák segítségével regisztráljuk a szöveteken mérhető feszültséget, majd transzimpedancia-mátrixszá alakítjuk a mért értékeket.

Eredmények: Az elektródasor visszatekeredése, amelyet korábban radiológiai vizsgálattal igazoltunk, az objektív elektrofiziológiai mérések segítségével is jól azonosítható, és a vizsgálatok szoros párhuzamot mutatnak.

Következtetés: Az elektródák helyzetének megjelenítésére szolgáló standard radiológiai képalkotási technikák kiegészíthetők, illetve kiválthatók egyszerúen elvégezhető, hatékony, objektív elektrofiziológiai vizsgálatokkal. Intraoperatíven, még a sebzárás előtt kimutatható, ha az elektródasor nem megfelelő helyzetbe került, így csökkenthetjük a radiológiai vizsgálatokkal járó sugárterhelés és annak finanszírozási problémáját.
\end{abstract}

Orv Hetil. 2021; 162(25): 988-996.

Kulcsszavak: cochlearis implantátum, Slim Modiolar elektródasor, transzimpedancia-mátrix, visszatekeredés

\section{Detection of "tip fold-over" of the cochlear implant electrode array with transimpedance matrix (TIM) measurement}

Introduction: In recent years, the cochlear implant has become a routine and effective treatment tool for severe hearing loss and total deafness. One of the commonly used and effective innovations of our time in cochlear implantation is the perimodiolar thin electrode array. The atraumatic electrode array, which closely embraces the central axis of the cochlea (modiolus), has served its popularity with very convincing results, with its performance in both electrophysiological measurements and acoustic hearing preservation. However, very few publications describe the frequency of improper positioning of the electrode array, which is known as 'tip fold-over'.

*N. R. és P. Á. megosztott első szerzőként jegyzik a kéziratot. 
Objective: The aim of our study is to incorporate a software technique, the transimpedance matrix (TIM), into routine intraoperative electrophysiological measurement methodologies to provide a potential objective diagnostic opportunity for early detection of tip fold-over of the electrode array.

Method: Following bilateral cochlear implantation of a three-year-old child, postoperative radiography showed the correct position of the electrode array on the left side, while tip fold-over of the intracochlear electrode array was detected on the right side. Following imaging, a TIM study was performed as an electrophysiological method. During the procedure, the measuring device transmits a voltage of the order of $1 \mathrm{~V}$ to the nearby structures of the cochlea at a constant current at the designated stimulus electrodes. Measuring electrodes were used to register the voltage measured on the tissues, and then converted into a TIM.

Results: Electrode tip fold-over was previously diagnosed by radiological examination, while it can also be diagnosed by objective electrophysiological measurements now, and these two tests correlate well.

Conclusion: Standard radiological imaging techniques for electrode positioning can be supplemented or replaced by easy-to-perform, effective objective electrophysiological studies. Tip fold-over can be detected intraoperatively, even before wound closure, if the electrode array is in the wrong position, thus reducing the radiation exposure associated with radiological examinations as well as reducing relevant costs.

Keywords: cochlear implant, Slim Modiolar electrode array, transimpedance matrix, tip fold-over

Nagy R, Perényi Á, Dimák B, Csanády M, Kiss JG, Rovó L. [Detection of “tip fold-over” of the cochlear implant electrode array with transimpedance matrix (TIM) measurement]. Orv Hetil. 2021; 162(25): 988-996.

(Beérkezett: 2020. szeptember 27.; elfogadva: 2020. november 26.)

\section{Rövidítések}

$\mathrm{AP}=$ akciós potenciál; $\mathrm{CI}=$ cochlearis implantátum; $\mathrm{CT}=$ (computed tomography) komputertomográfia; EFI = (electric field imaging) elektromosmező-képalkotás; ESRT = (electrical evoked stapedius reflex) elektromosan kiváltott stapediusreflex; $\mathrm{EVT}=$ (electric voltage tomography) elektromosfeszültségtomográfia; IFT = (impedance field telemetry) impedanciamező-telemetria; MRI = (magnetic resonance imaging) mágnesesrezonancia-képalkotás; NRT $=$ (neural response telemetry $)$ idegiválasz-telemetria; $\mathrm{SOE}=($ spread of excitation $)$ a gerjesztés terjedése; TIM = transzimpedancia-mátrix

A cochlearis implantátumok (CI-k) mútéti úton beültetett ideg-, szőrsejtprotézisek, amelyek az utóbbi években rutinszerú és hatékony kezelési eszközzé váltak a súlyos fokú halláskárosodás vagy a teljes siketség állapotának esetén [1-3]. Ezen koncepció az első implantáció óta igen sokat fejlődött, és manapság több befolyásoló tényező́t azonosítottak vagy éppen alkottak meg, melyek nagyban módosíthatják a hallásrehabilitáció kimenetelét. Idetartozik a mútéti megközelítés (cochleostoma vagy a kerekablak-megközelítés), az alkalmazott elektródatípus (egyenes - laterális falra illeszkedő vagy előgörbített perimodiolaris elektródasor) és az elektródasor cochleán belüli végső lokalizációja a (scala tympani és/vagy scala vestibuli) $[3,4]$. Számos tanulmány igazolja a kereskedelmi forgalomban jelen lévő, minimálinvazív módszerekkel behelyezett, vékony perimodiolaris elektródák pozitív tulajdonságát. A cochlea középtengelyét, a modiolust szorosan ölelő atraumatikus elektródasor igen meggyőző eredménnyel bizonyítja népszerúségét, mind az elektrofiziológiai mérések során, mind az akusztikus hallás megőrzése terén nyújtott teljesítményével. A kü- lönleges kialakítással bíró elektródavégpontok a töltésátadás szempontjából hatékonyabbak, mint vastagabb társaik, mindemellett kevésbé destruktívak az elektródasor bevezetésekor, és jelenlétük sem zavarja a kialakuló haladóhullámot a folyadéktérben [5-12]. Ugyanakkor nagyon kevés publikáció írja le az elektródasor nem megfelelő helyzetének előfordulási gyakoriságát, pontosabban a csúcs visszatekeredését (tip fold-over). A visszatekeredést számos tényező alakíthatja: 1) kicsi az elektróda keresztmetszeti átmérője, így elegendő hely van a scala tympaniban való betekeredéshez az oldalfal vagy a basalis membrán megsértése nélkül; 2) preoperatív képalkotók segítségével nem regisztrált rendellenesség kerülhet az elektródasor útjába a behelyezéskor, mely visszafordíthatja az előre görbített, flexibilis típusú elektródasort [13-15].

Az elektródasor visszatekeredését hagyományosan intraoperatív képalkotással, a leggyakrabban posztoperatív röntgenfelvétel segítségével vagy intra-, posztoperatív komputertomográfiával (CT), esetleg intraoperatív fluoroszkópiával azonosítják. A fluoroszkópia lehetósége egyértelmûnek tûnhet, mivel az operáció alatt figyelemmel kísérhető az elektródainszerció folyamatos mozgóképes eljárással, ám a technika alkalmazásához nagy tapasztalatra van szükség a beállított optimális nézet összehangolásához és a sugárterhelés korlátozásához a beteg és az intraoperatív személyzet számára. Másrészről igen kevés mútóállomás bír ezen technikai felszereléssel. Sok esetben egy „,egyszerü” röntgenberendezés üzemeltetésére sem áll rendelkezésre a technikai vagy akár sugárvédelmi háttér, mindemellett a képalkotás megnöveli az eljárás költségeit és időtartamát, de említhetjük a beteget éro „sugárterhelés” kockázatát is [16-18]. 
A legtöbb esetben csak az általános intraoperatív audiológiai/elektrofiziológiai teszteket hajtják végre az elektróda funkcionalitásának, lokalizációmeghatározásának érdekében. Ezek a mérési technikák sokszor normálisnak értékelhető eredményekkel szolgálnak a visszafordult elektródasorok állapotáról, fóként azon elektródák esetében, amelyek igen közeli helyzetet vesznek fel a modiolushoz.

Korábbi publikációk ismertetik más speciális telemetrikus válaszok hasznosságát annak érdekében, hogy kimutassák a visszatekeredés jelenlétét. Ezek a válaszok elsősorban a gerjesztés terjedését (spread of excitation - SOE) és az elektromosmező-képalkotást (electric field imaging - EFI) jellemzik. Míg a SOE az egyes elektródák körüli neuralis gerjesztőmezők szelektivitását ábrázolja, addig az EFI az intracochlearis elektródpárok egyes kombinációi közötti elektromos impedanciát és feszültségváltozást vizsgálja. Mindkét forgatókönyv szerint az a hipotézis, hogy az elektróda-visszatekeredés kapcsán az átfedő elektródák jelenléte esetén további, eltérő válasz is jelen van [19-24].

A Szegedi Tudományegyetem Fül-Orr-Gégészeti és Fej-Nyaksebészeti Klinikáján 2015 novembere óta öszszesen 156 vékony perimodiolaris elektródasor került beültetésre. Azóta 5 visszatekeredést regisztráltunk $(3,2 \%)$, melyeket posztoperatív röntgenfelvétel segítségével határoztunk meg. Azonnali intraoperatív diszlokáció feltárására nincs mód a mútőben, csak a mútétet követő radiológiai képalkotó módszerekkel. Emiatt második beavatkozás alkalmával történhet meg a visszatekeredés korrekciója, ami megterhelő mind a páciens, mind a személyzet számára, és még a finanszírozottság szempontjából is.

\section{Célkitúzés}

Tanulmányuk célja olyan szoftveres technika beillesztése a rutin intraoperatív mérési metodikák közé, amely potenciális eredményeket biztosít az elektródasor-visszatekeredés korai felismeréséhez. 2020 júniusában a közös kooperációt megkezdve ezen kutatási eszköz továbbfejlesztéséhez, a CI-t gyártó vállalat biztosított számunkra egy kiegészítő szoftvert, amely igen jó közelítéssel határozza meg az elektródasor rendellenes állapotát. Klinikai vizsgálatunk során az alkalmazott szoftver objektív mérési eredményeket regisztrál mútét közben és azt követően, annak érdekében, hogy igazolja a csigában található elektródasor elektromos tulajdonságait, állapotát és annak helyzetét a behelyezés után. Célunk az új diagnosztikai lehetőség részletes bemutatása egy eset segítségével.

\section{Módszer}

Klinikai protokollunknak megfelelően minden beteget kivizsgálunk a mútétet megelőzően radiológiai képalkotás segítségével. Általános esetekben nagy felbontású (0,8-1,25 mm szeletvastagság) CT-vizsgálatot alkalmazunk, amelyet lehetőség szerint a legtöbb esetben mágnesesrezonancia-képalkotás (MRI) eljárással egészítünk ki. Ha az anamnézis bakteriális meningitisre vagy hallóideg-aplasiára utal, az MRI nélkülözhetetlen. Ezek alapján a mütét menetét előre meg lehet tervezni, hogy a páciens számára a lehető legjobb típusú elektródasort válasszuk.

Tanulmányunkban egy eset segítségével mutatjuk be objektív transzimpedanciamátrix (TIM)-vizsgálatunkat. Nőbetegünk 2017-ben született. Veleszületett hallás-
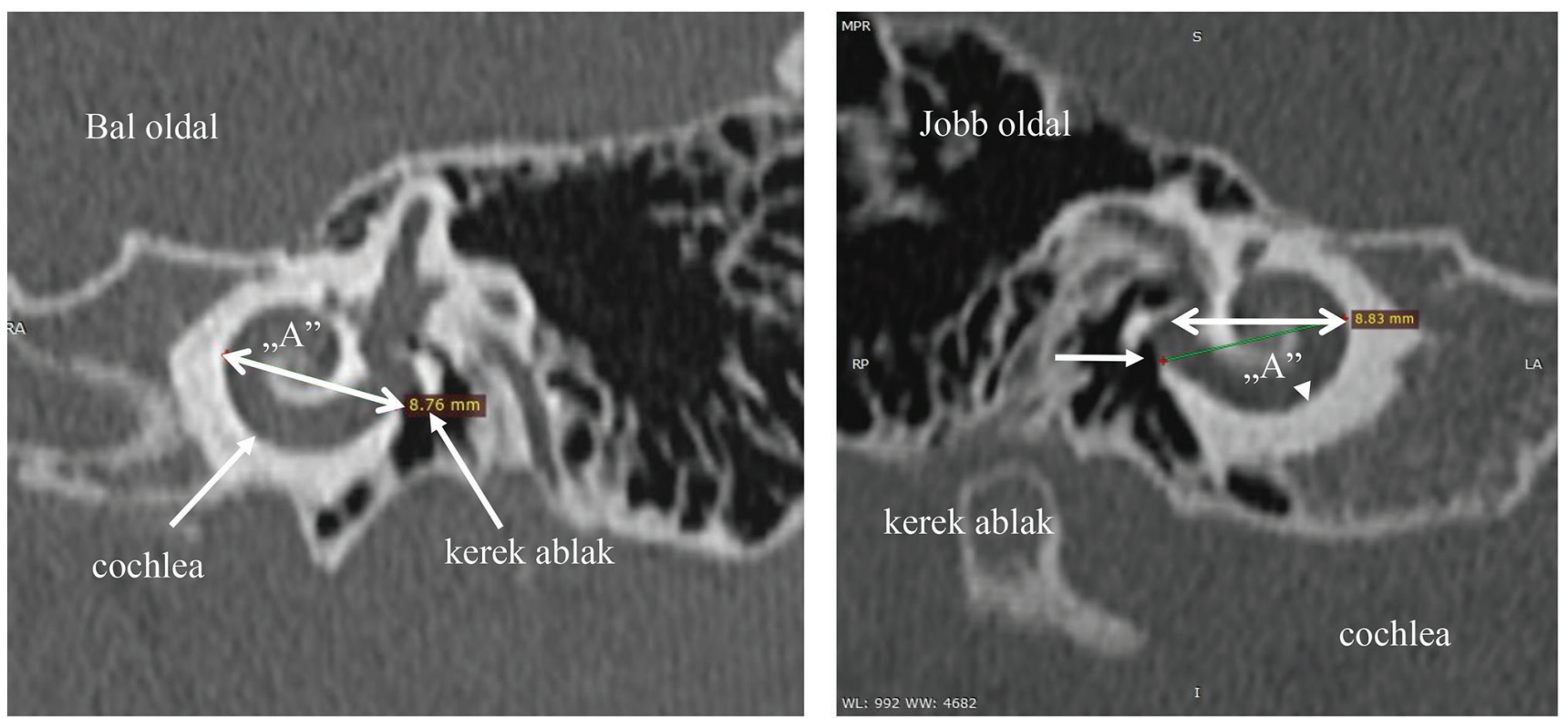

1. ábra

Preoperatív komputertomográfiás (CT-) vizsgálat mindkét oldal esetén. Az implantáció előtti kivizsgálás részeként elvégzett képalkotó (CT-) vizsgálat eredménye alapján mindkét oldali cochlea szabályos alakú és méretű, a kerek ablak szabályos, és a cochlea-folyadéktéren belül obstrukcióra utaló kóros denzitásérték nem detektálható. A mastoidalis sejtrendszer az életkornak megfelelően fejlett és légtartó. A nervus facialis lefutása szabályos. Az „A” átmérő jobb oldalon $8,83 \mathrm{~mm}$, míg a bal oldalon $8,76 \mathrm{~mm}$, mely értékek alapján közepes méretű cochleának megfelel 
csökkenése 1 éves korában igazolódott. A gyermeket a kétoldali, súlyos fokú, nagy teljesítményű hallókészülékkel érdemben nem javítható idegi típusú halláscsökkenése miatt vettük fel Klinikánkra. Mútéti alkalmasságát részletes radiológiai tesztekkel bíráltuk el. A közép- és a belső fül csontos képletei mindkét oldalon szabályos lefutásúak és tágasságúak (1. ábra).

Az implantációt a beteg 3. életévében végeztük el általános anesztéziában. Mivel a betegnek a mútétet megelőzően kiértékelt radiológiai vizsgálatai nem mutattak rendellenességet, a cochlea jól átjárható volt, így mindkét fülén vékony perimodiolaris elektródasor (CI632 Slim Modiolar implantátum; Cochlear Ltd., Sydney, Ausztrália) alkalmazása mellett döntöttünk. A mútétet minimálisan invazív sebészi technikát alkalmazva kerek ablakos megközelítéssel végeztük [7].

\section{Nucleus Slim Modiolar elektródasor}

Az elektródasorokat a modiolustól való távolságuk alapján három kategóriába sorolhatjuk: 1. perimodiolaris, 2. „mid-scala”, 3. „lateral-wall”. A Nucleus Slim Modiolar elektródasor jelenleg a világ egyik legvékonyabb perimodiolaris elektródasora (átméróje basalisan 0,5 mm, apicalisan $0,3 \mathrm{~mm}$ ). Kialakítása lehetővé teszi, hogy az elektródák a lamina spiralis ossea eredése alatt, a modiolushoz szorosan helyezkedjenek el, ami biztosítja, hogy az elektródavégpontok a ganglion spirale közelében foglaljanak helyet. Atraumatikus tulajdonságai biztosítják az endocochlearis finomstruktúrák megőrzését, melyet bevezetéskor egy speciális újratölthetô vezetőeszköz támo- gat. A minimálinvazív beavatkozás során a vezetőeszköz segíti a helyes inszerciós szög megválasztását, biztosítva a könnyed, sima behelyezést [5-9, 25-27].

\section{Intraoperatív audiológiai mérések}

Az implantátumgyártók két mérési technikát ajánlanak, amelyet érdemes minden esetben elvégezni. Az első módszer az impedancia (váltakozó áramú ellenállás) ellenőrzése, azaz az elektródasor minden elektródáján külön-külön mért referenciapontokhoz képest megállapított ellenállásérték. Az impedanciaértékek az elektródasor állapotáról adnak információt: nincs szakadás, van stabil vezetőközeg. A másik metodika az idegiválasz-telemetria (neural response telemetry - NRT), amely a stimulálandó idegelemekról ad információt. Múködését tekintve egyszerre két elektródakivezetés aktív. Az egyik elektróda egy stimuláló ingert küld, melynek hatására a környező idegsejtekben akciós potenciál (AP) jön létre. A másik aktív elektróda képes a kiváltott AP-t regisztrálni, így képet kaphatunk a hallóidegpálya cochlearis végződésének aktivitásáról. Ezen regisztrált NRT-értékek igen jó becslésül szolgálhatnak a későbbiekben a készüléken keresztül elektromosan kiváltott küszöbértékek beállításához (hallás- és komfortküszöb) [25, 28-32].

Egyéb intraoperatív mérési lehetőség is rendelkezésre áll, melyet klinikánkon is alkalmazunk, úgymint az elektromosan kiváltott stapediusreflex (ESRT) küszöbértékének regisztrálása. Mútéti technikától függően láthatóvá válik a stapediusín, amely erős zaj hatására összehúzódik, így merevebbé válik a hallócsontlánc, amely kevésbé

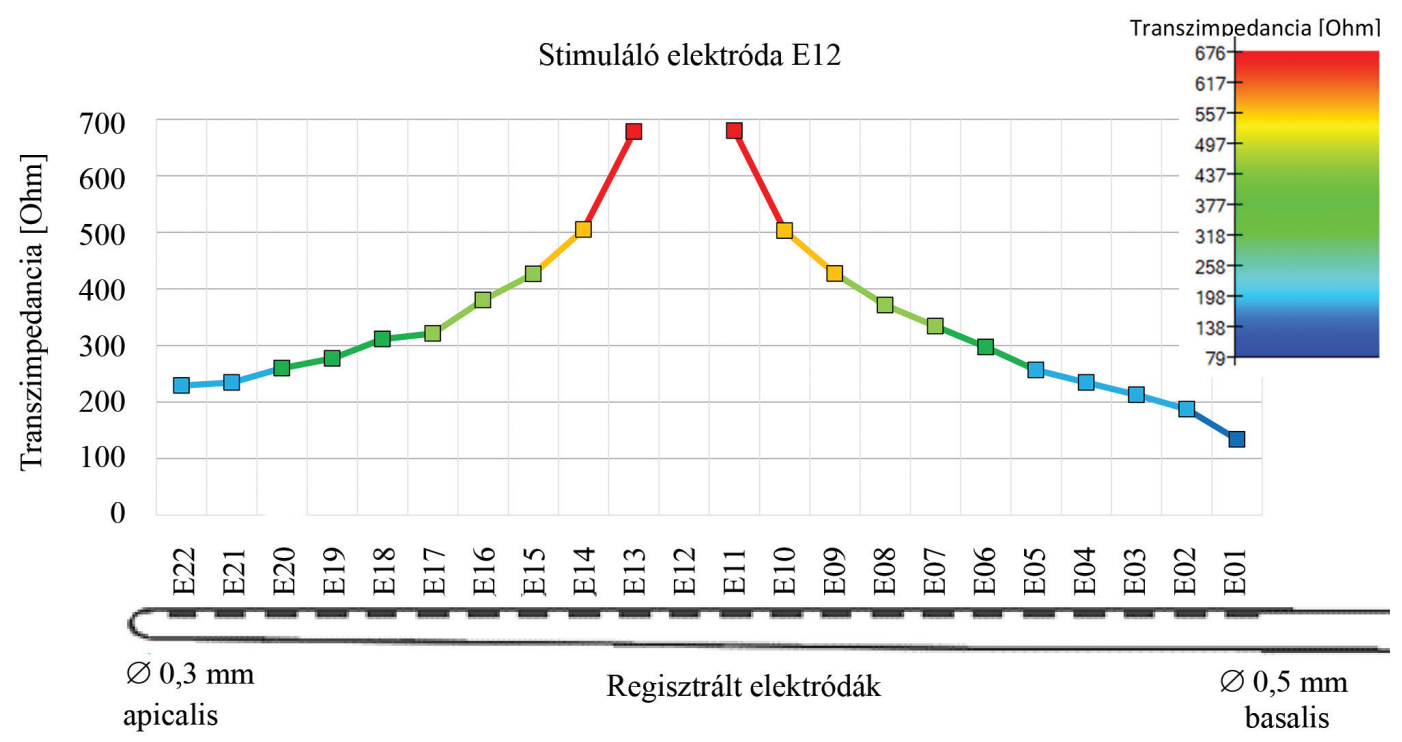

2. ábra $\quad$ Transzimpedancia-mérési eredmények a 12. elektródán keresztüli stimulációval. A transzimpedancia-mátrix meghatározásakor az elektródasor minden egyes végpontján adott áramerősség mellett stimuláljuk a legközelebb eső intracochlearis régiókat. A jelen esetben az E12-es elektróda szolgál stimuláló végpontként, és a többi végpont regisztráló elektródaként múködik. Minél közelebb esik a stimulátor az adott regisztráló elektródákhoz, annál nagyobb feszültségértéket tud rögzíteni a közeli intracochlearis régióról. Ennek alapján, ha elektródasor-visszatekeredés történt az apicalis régióban ( E15-E22), tehát az elektródasor végén található - E22, E21, E20 stb. - elektródák közelebb kerülnek a kisebb sorszámmal jelölt stimuláló elektródához, úgy közel azonos mértékű feszültséget mérhetünk, mint a stimuláló elektróda közvetlen környezetében lévők esetében. A rögzített feszültségértékeket Ohm törvénye alapján osztjuk a konstans áramerősséggel, aminek segítségével megkapjuk az impedanciaértékeket 
vezeti jól a hang keltette rezgést, ezzel védve a belső fület. Ha intracochlearisan nagy intenzitású elektromos ingert indítunk meg a belső elektródák segítségével, úgy mesterségesen is kiválthatjuk az apró izom összehúzódását, s e legkisebb látható mozgást kiváltó inger intenzitásértékét rögzítjük [33-35].

\section{Transzimpedancia-mátrix (TIM)}

A TIM egy elektrofiziológiai diagnosztikai eszköz transzimpedanciák mérésére és megjelenítésére. A szakirodalomban az elméleti metodika vagy éppen más gyártók esetében - egymás szinonimájaként - több néven is ismert, mint például elektromosmező-képalkotás (EFI), impedanciamező-telemetria (impedance field telemetry - IFT) és elektromosfeszültség-tomográfia (electric voltage tomography-EVT). A Cochlear Nucleus új perimodiolaris elektródasorral ellátott implantátumok alkalmazása szükségessé tette az elmélet gyakorlatba ültetését.

A metodika alapelve, hogy az eszköz az egyik elektróda (stimuláló elektróda) által indukált intracochlearis feszültséget méri az összes többi elektróda segítségével (regisztráló elektróda), amely az intracochlearis stimuláló kontaktus és az extracochlearis referenciaelektróda között van jelen. Az elektródasoron 22 elektródavégpont talál- ható. 22 mérés történik egymást követően, melyben 1 stimuláló és 21 regisztráló elektróda vállal felváltva szerepet. Egységesen, elektródánkként előre meghatározott állandó (konstans) áramerősség mellett stimulálunk egy adott cochlearégiót. A stimulált régió környezetéből a regisztráló elektródák segítségével feszültséget mérhetünk (2. ábra). A rögzített feszültségértékekból feszültségmátrixot hozunk létre. A feszültségmátrixot ezután transzimpedancia-mátrixszá alakítjuk, elosztva az egyes feszültségméréseket a stimuláló árammal (Ohm törvénye), így megkapjuk a transzimpedancia értékét az elektródasorra vonatkozólag (intracochlearis áram folyik az intracochlearis kontaktus és az extracochlearis referenciaelektróda között) [19, 23]. A TIM-et „hőtérkép” segítségével jelöljük. Mesterséges színskála alapján soroljuk be a kialakított értéket, amely a mátrixban jól jelöli az elektródasoron lévő végpontok egymáshoz viszonyított helyzetét. Minél közelebb esik egy méróelektróda a stimuláló elektródához, annál „melegebb” színt kap, azaz a stimuláló elektróda szomszédságában lévő regisztráló végpontokon mért érték magas, így azt piros színnel jelölhetjük, míg a távolikat inkább a kékbe nyúló színekkel (3. ábra).

Az intraoperatív elektrofiziológiai mérések (impedancia, NRT, ESRT, TIM) Cochlear Custom Sound 5.2 szoftverrel valósultak meg (Cochlear Ltd.).
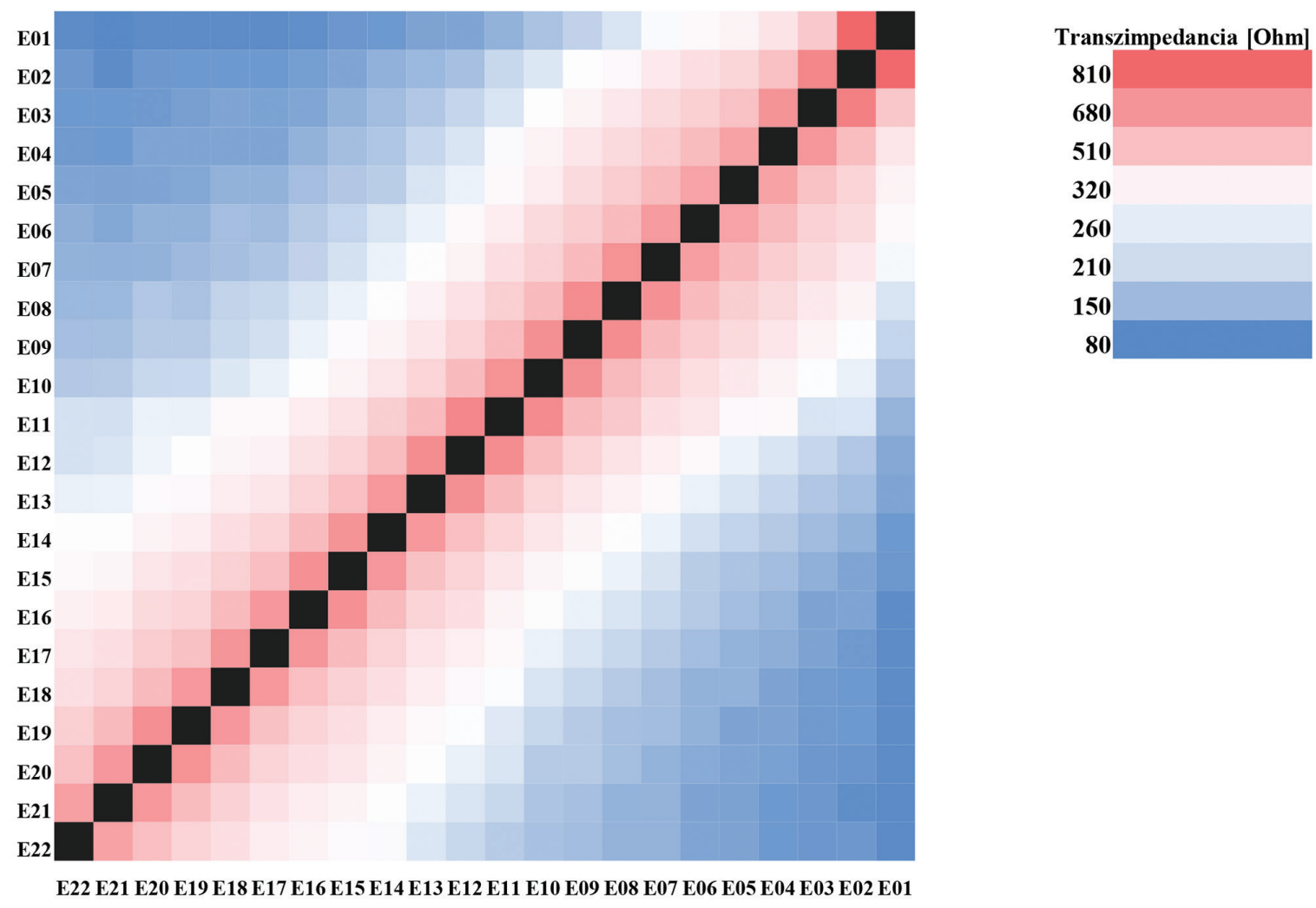

3. ábra

Transzimpedanciamátrix-hőtérkép

A transzimpedancia-mátrixot „hőtérkép” segítségével jelöljük. A sötét mátrixpontátló stimuláló elektródákat jelöl. A stimuláló elektródák szomszédságába eső mérőelektródákon magasabb feszültséget, tehát magasabb transzimpedancia-értékeket kapunk, mint a távolabb esőkön, így azokat „mele gebb" színekkel, pirossal jelöljük. A távolabb eső mérőelektródák alacsonyabb értékeket vesznek fel, így azok „hidegebb”, azaz kékbe nyúló jelölést kapnak. Ha a stimuláló elektródához távolabb lévő méróelektródán is magas értéket kapunk, amely a sötét mátrixpontátlótól távolabb, inkább a mátrix széle felé jelenik meg piros, sötétnarancs színekkel, az arra enged következtetni, hogy visszatekeredés történt 

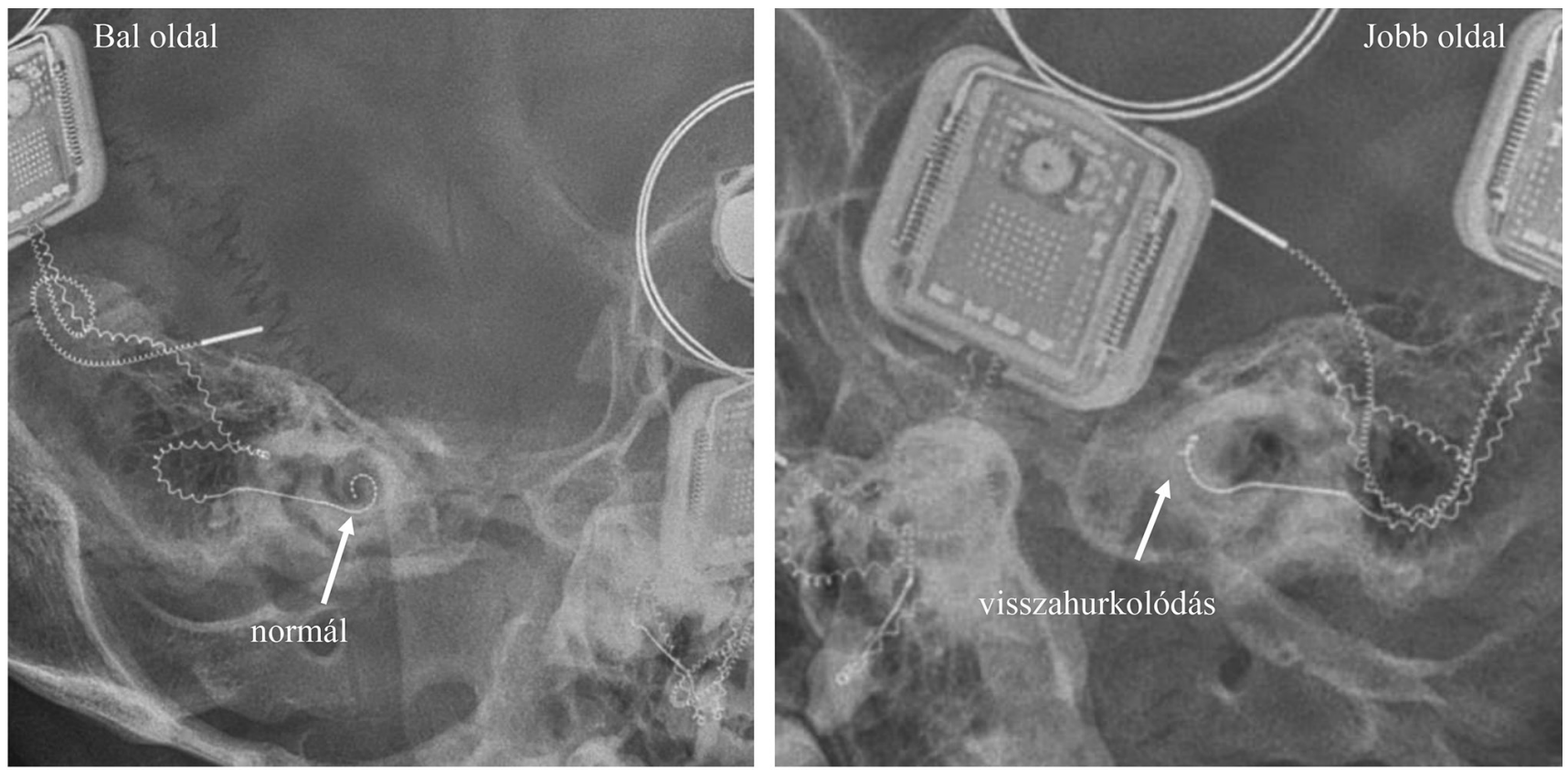

4. ábra

Posztoperatív kétoldali kontrollröntgen. Az implantációt követő első napon készített anteroposterior és módosított Stenvers-felvétel tanúsága szerint a jobb oldalra beültetett elektródasor a cochleán belül visszacsavarodott, míg a bal oldalon normálhelyzetbe került

\section{Eredmények}

Kiemelt esetünkben TIM-vizsgálatot végeztünk, melynél egyidejú bilaterális implantáció történt. Posztoperatív méréseink folyamán páciensünk nem tapasztalt kellemetlenséget, csak halk hangjelzésre lett figyelmes. Posztoperatív röntgenfelvételen megállapíthatóvá vált páciensünknél az elektródasor csúcsi szakaszán a rendellenes pozíció a jobb oldali rendszer esetében, míg a bal oldali rendszer megfelelő helyzetet vett fel (4. ábra).

A bal oldali készülék esetében a kialakított mátrix segítségével jól kivehetô, hogy a stimuláló elektródákat jelölő, sötét színú átlós pontsorozat környezetében halmozódik fel a legtöbb piros mátrixpont, azaz azon a területen a legmagasabbak a transzimpedancia-értékek. Ez a jelenség megfelelően behelyezett elektródasorra utal (5. ábra).

A jobb oldali CI esetében létrehozott mátrix egy fontos részletben tér el a bal oldalitól (3. ábra), mégpedig hogy a sötét átló közvetlen környezetén kívül is találunk piros, narancs mátrixpontokat. Ez a különbség annyit tesz, hogy hasonló transzimpedancia-értékkel bíró, távolabbi mérőelektróda-végpontok is jelen vannak, mint a stimuláló elektróda közvetlen környezetében lévőkön mért értékek. Ezen rendellenes jelenség radiológiai igazolás nélkül is visszatekeredett elektródasorra enged következtetni (6. ábra).

\section{Következtetés}

A legkorszerúbb eljárások tudatos alkalmazásával jelentôsen hozzájárulhatunk a népegészségügyi mutatók javításához. Az elektródák helyzetének igazolására szolgáló standard eljárások jelenleg radiológiai képalkotási technikák, például CT vagy röntgen segítségével történnek. A lehetőségektől függően a CT-vizsgálatok vagy a röntgenfelvétel készítése előnyös lehet a betegek számára, növeli az intraoperatív objektív mérések megbízhatóságát, segíti az elektródasor elektromos tulajdonságainak jellemzésével kapott eredmények igazolását.

A modern CI-rendszerek elektróda-végpontjai átkonfigurálhatók stimulálásról rögzítésre. Az utóbbi kellőképpen finom pontossággal bír ahhoz, hogy regisztrálja a perifériás hallóideg biológiai válaszát $( \pm 0,1 \mathrm{mV})$, de TIM esetében az implantátum úgy van konfigurálva, hogy képes legyen rögzíteni a sokkal nagyobb elektromos stimulációs mezőt is $( \pm \mathrm{l} \mathrm{V})$. Az összes elektródavégpont mentén egy intracochlearis potenciálprofilt, elektromos kiterjedési görbét rögzítünk, amikor egyetlen kontaktuson keresztül monopoláris módban stimulálunk, vagyis áram áramlik az intracochlearis kontaktus és az extracochlearis referenciaelektróda között. Annak érdekében, hogy a stimuláció erőssége csak a cochlearis szövet ellenállását tükrözze, az elektródákon regisztrált feszültségértékeket elosztjuk az adott konstans áram mértékével. Ezután az eloszlási görbék oszloponként összeilleszthetók egy mátrixba, amely tartalmazza a transzimpedancia-értékeket [20-23].

A tanulmány a TIM-tesztszoftver múködését vizsgálja, dokumentálja a normális és a visszatekeredett elektródasorral rendelkező esetekben mért eredményeket. A jelenlegi verzió alapvetően kutatási célokra van kialakítva, ám a vizsgálati rutint jól kiegészíti. Tesztjellege ellenére jelentős gyakorlati nehézségek nem voltak a szoftver jelenlegi formájában történő használata során. Nem jelentkeztek kényelmetlen, nehezen kezelhető 


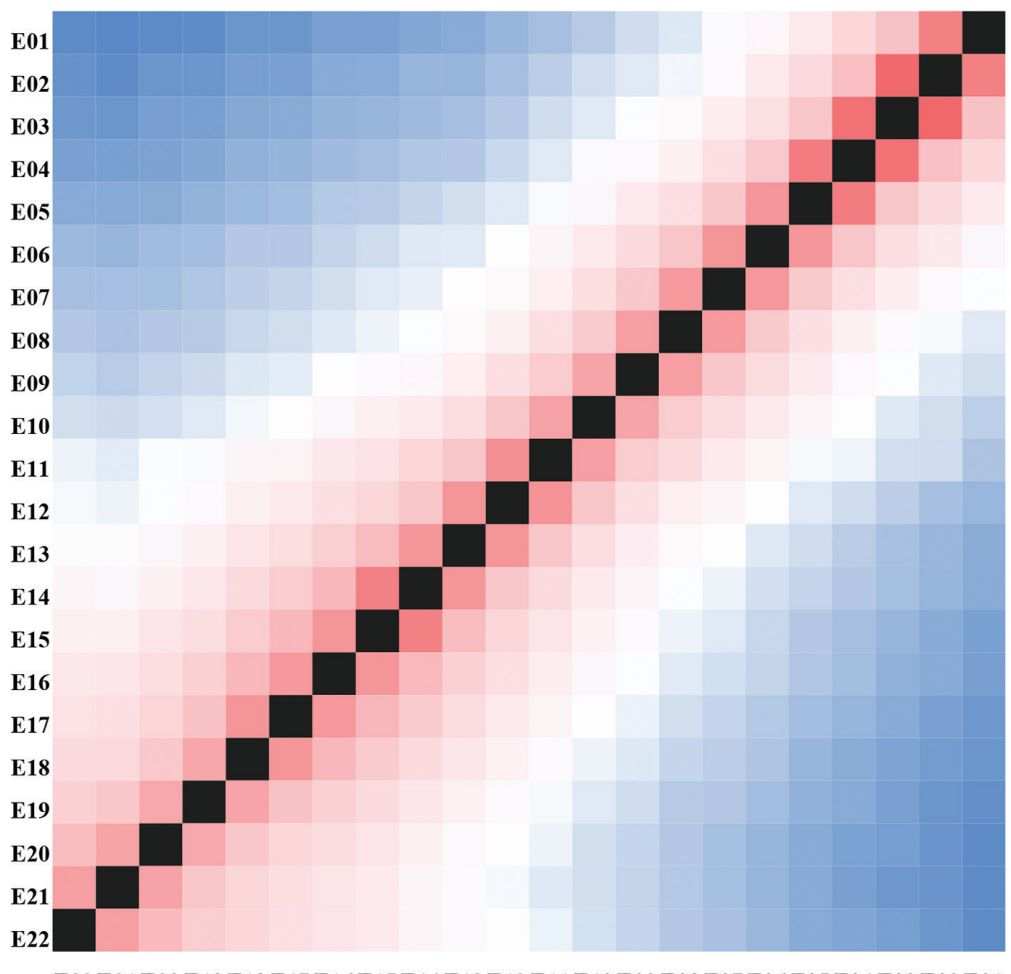

Transzimpedancia $[\mathrm{Ohm}]$
1650
1450
1300
1100
1000
950
855
730

\section{E22 E21 E20 E19 E18 E17 E16 E15 E14 E13 E12 E11 E10 E09 E08 E07 E06 E05 E04 E03 E02 E01}

5. ábra

Transzimpedancia-mátrix alapján normál helyzetú elektródasor. Méréseink során a bal oldali CI-rendszer esetében igazoltuk az elektródasor megfeleló pozícióját. Jól látható, hogy a hőtérképeken a melegebb színek a sötét mátrixpont, azaz a stimuláló elektródák területén tömörülnek, ami a megfeleló elhelyezkedésre utal

$\mathrm{CI}=$ cochlearis implantátum

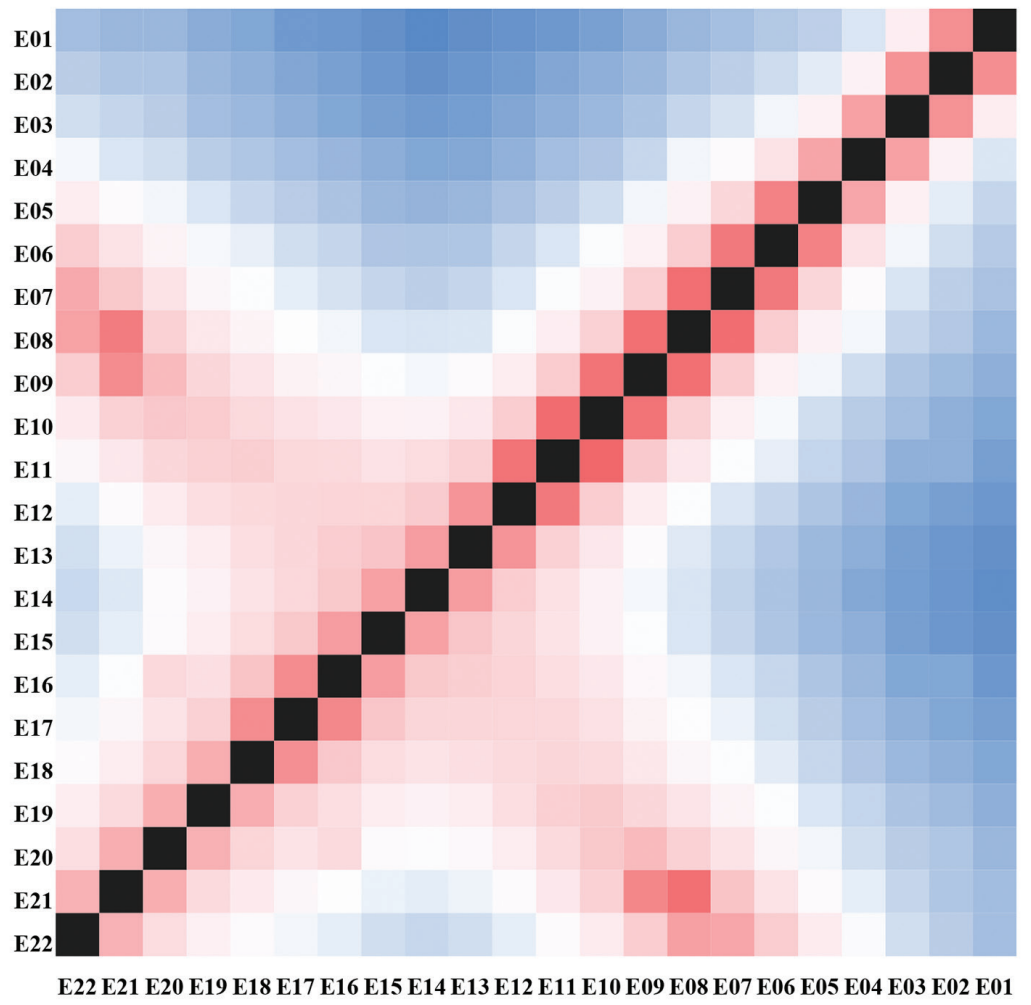

Transzimpedancia [Ohm]
1870
1600
1350
1180
1050
980
855
790

6. ábra

Transzimpedancia-mátrix alapján visszatekeredett elektródasor. A jobb oldali implantátum esetében kaptunk olyan eredményt, amely a behelyezett elektródasor visszatekeredésére utal. A sötét mátrixpontátlótól távolabb eső mérési pontokon is magas transzimpedancia-érték alakult ki, ami a hőtérképeken piros, narancsos árnyalatú mátrixpontokat eredményezett. Az eltérő jelenség az elektródasor rendellenes helyzetére utal 
problémák. A vizsgálat megismételhetőségi rátája nagyon biztató, mivel igen szoros összefüggés volt az intraoperatív és a posztoperatív objektív vizsgálatok és radiológiai eredmények között.

A módszer igazolását nagyban elősegíti a modern radiológiai technológiák kísérete. Nemcsak az intraoperatív elektrofiziológiai módszereket támogatja, de az operáló személyzetnek is jelentős biztonsági hátteret ad, ami egyedülálló lehetőségeket nyújt.

Anyagi támogatás: A közlemény megírása, illetve a kapcsolódó kutatómunka anyagi támogatásban nem részesült.

Szerzői munkamegosztás: N. R.: Az elektrofiziológiai mérések elvégzése, az ábrák megszerkesztése, a kézirat elkészítése. P. Á.: A cochlearis impantációs kivizsgálás megszervezése, részvétel a mútét folyamatában, a kézirat véleményezése, az ábrák elkészítése. D. B.: Az elektrofiziológiai mérések elvégzése. Cs. M.: A kézirat véleményezése, publikációra való felkészítése. K. J. G.: Az elektrofiziológiai mérések ellenőrzése, eredményeik értékelése; tudományos tanácsadás. R. L.: Az implantációs team vezetóje, a cochlearis implantáció elvégzése, a beteg posztoperatív gondozása, a végleges kézirat véleményezése; a publikáció folyamatának nyomon követése, irányítása. A cikk végleges változatát valamennyi szerző elolvasta és jóváhagyta.

Érdekeltségek: A szerzőknek nincsenek érdekeltségeik.

\section{Irodalom}

[1] Chiossi JS, Hyppolito MA. Effects of residual hearing on cochlear implant outcomes in children: a systematic-review. Int J Pediatr Otorhinolaryngol. 2017; 100: 119-127.

[2] Katona G, Küstel M. Hearing improvement with implantable hearing aids in children. [Hallásjavítás implantálható hallókészülékekkel gyermekkorban.] Gyermekgyógyászat 2016; 67: 113118. [Hungarian]

[3] Perényi Á, Jóri J, Csanády M, et al. Dimensions of the human temporal bone that are relevant to cochlear implantation surgery in infants and toddlers. A clinical-radiological study. [Az emberi halántékcsontnak a csecsemő- és kisgyermekkori cochlearis implantáció szempontjából kiemelkedően fontos dimenziói. Klinikoradiológiai vizsgálat.] Orv Hetil. 2019; 160: 936-943. [Hungarian]

[4] Eshraghi AA, Nazarian R, Telischi FF, et al. The cochlear implant: historical aspects and future prospects. Anat Rec (Hoboken). 2012; 295: 1967-1980.

[5] Perényi Á, Nagy R, Dimák B, et al. The distance from the modiolus of perimodiolar electrode arrays of cochlear implants. A radiological study to evaluate the difference in perimodiolar properties. [Cochlearis implantátumok különböző, elôre görbített elektródasorainak elhelyezkedése a cochlea tengelyéhez viszonyítva. Radiológiai vizsgálat a perimodiolaritás mértékének megállapítására.] Orv Hetil. 2019; 160: 1216-1222. [Hungarian]

[6] Perényi A, Tóth F, Nagy AA, et al. Early experience on a modern, thin cochlear implant family. A retrospective, international multicenter study. J Med Life 2018; 11: 146-152.
[7] Perényi A, Tóth F, Dimák B, et al. Electrophysiological measurements with electrode types of different perimodiolar properties and the same cochlear implant electronics - a retrospective comparison study. J Otolaryngol Head Neck Surg. 2019; 48 : 46.

[8] Nagy R, Jarabin JA, Dimák B, et al. Possibilities for residual hearing preservation with Nucleus CI532 Slim Modiolar electrode array. Case report. [A maradványhallás megőrzésének lehetőségei cochlearis implantáció során Nucleus CI532 Slim Modiolar elektródasorral.] Orv Hetil. 2018; 159: 1680-1688. [Hungarian]

[9] Nagy R, Jarabin JA, Perényi Á, et al. Long-term hearing preservation with Slim Perimodiolar CI532 ${ }^{\circledR}$ cochlear implant array. Am J Otolaryngol Head Neck Surg. 2018; 1: 1019.

[10] Iso-Mustajärvi M, Sipari S, Löppönen H, et al. Preservation of residual hearing after cochlear implant surgery with slim modiolar electrode. Eur Arch Otorhinolaryngol. 2020; 277: 367375 .

[11] Ramos-Macias A, O'Leary S, Ramos-deMiguel A, et al. Intraoperative intracochlear electrocochleography and residual hearing preservation outcomes when using two types of slim electrode arrays in cochlear implantation. Otol Neurotol. 2019; 40: S29S37.

[12] Heutink F, Verbist BM, Mens LH, et al. The evaluation of a slim perimodiolar electrode: surgical technique in relation to intracochlear position and cochlear implant outcomes. Eur Arch Otorhinolaryngol. 2020; 277: 343-350.

[13] Dimák B, Nagy R, Perényi A, et al. Review of electrode placement with the slim modiolar electrode: identification and management. [Perimodioláris típusú elektróda behelyezése: Áttekintés és esettanulmányok.] Ideggyógy Szle. 2020; 73: 53-59. [Hungarian]

[14] Dhanasingh A, Jolly C. Review on cochlear implant electrode array tip fold-over and scalar deviation. J Otol. 2019; 14: 94100. [Erratum: J Otol. 2020; 15: 180.]

[15] Zuniga MG, Rivas A, Hedley-Williams A, et al. Tip fold-over in cochlear implantation: case series. Otol Neurotol. 2017; 38: 199-206.

[16] Fishman AJ, Roland JT Jr, Alexiades G, et al. Fluoroscopically assisted cochlear implantation. Otol Neurotol. 2003; 24: 882886.

[17] Coelho DH, Waltzman SB, Roland JT Jr. Implanting common cavity malformations using intraoperative fluoroscopy. Otol Neurotol. 2008; 29: 914-919.

[18] Stultiens JJ, Postma AA, Guinand N, et al. Vestibular implantation and the feasibility of fluoroscopy-guided electrode insertion. Otolaryngol Clin North Am. 2020; 53: 115-126.

[19] Cohen LT, Saunders E, Richardson LM. Spatial spread of neural excitation: comparison of compound action potential and forward-masking data in cochlear implant recipients. Int J Audiol. 2004; 43: 346-355.

[20] Vanpoucke FJ, Boermans PP, Frijns JH. Assessing the placement of a cochlear electrode array by multidimensional scaling. IEEE Trans Biomed Eng. 2012; 59: 307-310.

[21] de Rijk SR, Tam YC, Carlyon RP, et al. Detection of extracochlear electrodes in cochlear implants with electric field imaging/ transimpedance measurements: a human cadaver study. Ear Hear. 2020; 41: 1196-1207.

[22] Mens LH. Advances in cochlear implant telemetry: evoked neural responses, electrical field imaging, and technical integrity. Trends Amplif. 2007; 11: 143-159.

[23] Hey M, Böhnke B, Dillier N, et al. The Intra-Cochlear Impedance-Matrix (IIM) test for the Nucleus ${ }^{\circledR}$ cochlear implant. Biomed Tech (Berl). 2015; 60: 123-133.

[24] Grolman W, Maat A, Verdam F, et al. Spread of excitation measurements for the detection of electrode array foldovers: a prospective study comparing 3-dimensional rotational X-ray and intraoperative spread of excitation measurements. Otol Neurotol. $2009 ; 30: 27-33$. 
[25] Hey M, Wesarg T, Mewes A, et al. Objective, audiological and quality of life measures with the CI532 slim modiolar electrode. Cochlear Implants Int. 2019; 20: 80-90.

[26] Cuda D, Murri A. Cochlear implantation with the nucleus slim modiolar electrode (CI532): a preliminary experience. Eur Arch Otorhinolaryngol. 2017; 274: 4141-4148.

[27] McJunkin JL, Durakovic N, Herzog J, et al. Early outcomes with a slim, modiolar cochlear implant electrode array. Otol Neurotol. 2018; 39: e28-e33.

[28] Cuda D, Murri A. Assessment of cochlear trauma and telemetry measures after cochlear implantation: a comparative study between Nucleus ${ }^{\circledR}$ CI512 and CI532 electrode arrays. Audiol Res. 2019; 9: 223.

[29] Kiss JG, Tóth F, Nagy AL, et al. Neural response telemetry in cochlear implant users. Int Tinnitus J. 2003; 9: 59-60.

[30] Campbell L, Kaicer A, Sly D, et al. Intraoperative real-time cochlear response telemetry predicts hearing preservation in cochlear implantation. Otol Neurotol. 2016; 37: 332-338.

[31] Almosnino G, Anne S, Schwartz SR. Use of neural response telemetry for pediatric cochlear implants: current practice. Ann Otol Rhinol Laryngol. 2018; 127: 367-372.
[32] Campbell L, Kaicer A, Briggs R, et al. Cochlear response telemetry: intracochlear electrocochleography via cochlear implant neural response telemetry pilot study results. Otol Neurotol. 2015; 36: 399-405.

[33] Lorens A, Walkowiak A, Piotrowska A, et al. ESRT and MCL correlations in experienced paediatric cochlear implant users. Cochlear Implants Int. 2004; 5: 28-37.

[34] Wolfe J, Gilbert M, Schafer E, et al. Optimizations for the electrically-evoked stapedial reflex threshold measurement in cochlear implant recipients. Ear Hear. 2017; 38: 255-261.

[35] Kosaner J, Spitzer P, Bayguzina S, et al. Comparing eSRT and eCAP measurements in pediatric MED-EL cochlear implant users. Cochlear Implants Int. 2018; 19: 153-161.

(Nagy Roland dr., Szeged, Tisza Lajos krt. 111., 6725 e-mail: nagy.roland@med.u-szeged.hu)

\section{„Rivalitatem non amat victoria." (A diadal nem tür vetélytársat.)}

A cikk a Creative Commons Attribution 4.0 International License (https://creativecommons.org/licenses/by/4.0/) feltételei szerint publikált Open Access közlemény, melynek szellemében a cikk bármilyen médiumban szabadon felhasználható, megosztható és újraközölhető, feltéve, hogy az eredeti szerző és a közlés helye, illetve a CC License linkje és az esetlegesen végrehajtott módosítások feltüntetésre kerülnek. (SID_1) 